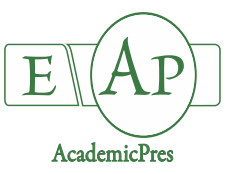

Ratknić T et al. (2021)

Notulae Botanicae Horti Agrobotanici Cluj-Napoca

Volume 49, Issue 2, Article number 12260

DOI: $10.15835 /$ nbha 49212260

Research Article

\title{
An analysis of the profitability of the restitution of sessile oak forests affected by wildfires in Serbia
}

\author{
Tatjana RATKNIĆ ${ }^{1}$, Mihailo RATKNIĆ ${ }^{2}$, Jonel SUBIĆ ${ }^{3}$, \\ Zoran PODUŠKA ${ }^{1}$, Gordana ŠEKULARAC ${ }^{4 *}$, \\ Miroljub AKSIĆs , Sunčica VJEŠTICA ${ }^{2}$ \\ ${ }^{1}$ Institute of Forestry, Kneza Višeslava 3, 11000 Belgrade, Serbia; tatjanaratknic@yahoo.com; zoran.poduska@gmail.com \\ ${ }^{2}$ Faculty of Applied Ecology - Futura, Požeška 83a, 11000 Belgrade, Serbia; mihailoratknic@yahoo.com; \\ suncica.vjestica@futura.edu.rs \\ ${ }^{3}$ Institute of Agricultural Economics, Volgina 15, 11000 Belgrade, Serbia; jonel_s@iep.bg.ac.rs \\ ${ }^{4}$ University of Kragujevac, Faculty of Agronomy, Cara Dušana 34, 32000 Cačak, Serbia; gordasek@kg.ac.rs (*corresponding author) \\ ${ }^{5}$ University of Priština, Kosovska Mitrovica, Faculty of Agriculture, Kopaonička bb, 38219 Lešak, Serbia; miroljubaksic@gmail.com
}

\begin{abstract}
Wildfires caused by climate change in Europe have numerous and long-lasting ecological, economic, and social implications for sustainable development (natural environment, economy, and society as a whole). Artificial revitalization of sessile oak forests destroyed by wildfires in Serbia is feasible, but it is quite expensive compared to the spontaneous regeneration. Cost-benefit analysis (an economic approach to comparing and estimating the benefits and shortcomings of a particular business plan, i.e., an investment project by analyzing its costs and benefits) is aimed at finding the best solutions and making the best decisions about the desirability of a project. It was concluded that the investment in the restitution of sessile oak forests could be profitable only if it was based on wood production. Wood production may bear slightly higher interest rates compared to previous estimates which ranged mainly around $3 \%$. This primarily applies to better site classes, while poor quality sites require lower rates. At lower discount rates, it takes more time to reach the break-even point, while the period of time needed to reach the break-even point shortens with higher discount rates. The length of the production cycle plays an important role in determining the investment profitability, especially regarding the relationship between the length of the production cycle and production targets (the type and the quality of wood assortments produced). According to the results of the analysis of intangible benefits and costs, the costs outweigh the benefits, which makes the restitution of sessile oak forests destroyed by fires unacceptable.
\end{abstract}

Keywords: economic analysis; financial analysis; restitution; sessile oak forests; wildfire

\section{Introduction}

Forest ecosystems are open systems with ecologic, economic, and social functions (Altun et al., 2016). From an economic point of view, the global significance of forests is reflected in the fact that more than 1.6 billion people are directly dependent on them, including more than ten million people employed in the forestry

Received: 10 Feb 2021. Received in revised form: 29 Mar 2021. Accepted: 12 Apr 2021. Published online: 29 Apr 2021.

From Volume 49, Issue 1, 2021, Notulae Botanicae Horti Agrobotanici Cluj-Napoca journal uses article numbers in place of the traditional method of continuous pagination through the volume. The journal will continue to appear quarterly, as before, with four annual numbers. 
sector. As a result of the constant changes in rural areas, the role of forestry is changing. In the past, forestry focused on the forest functions related to primary production in order to strengthen the economy of a rural area and provide work and income to the local population, as well as raw materials. Nowadays, forestry focuses mainly on the conservation, ecological balance of forests and forest areas, as well as enhancing those environmental benefits that upgrade the quality of life of the constantly increasing urban population (Arabatzis, 2010).

Since the beginning of the $20^{\text {th }}$ century, the global temperature has risen by $0.8^{\circ} \mathrm{C}$ (Hansen et al., 2010), while it is expected to increase by $2.8^{\circ} \mathrm{C}$ to $4-5^{\circ} \mathrm{C}$ (from the north to the south) in Europe by the end of the $21^{\text {st }}$ century (Christensen et al., 2007). Forests are very sensitive to climate change since they cannot easily adapt to changing environmental conditions. Climate change increases the risk of wildfire occurrence and spread (Allen et al., 2010). As droughts have been observed to increase in frequency, intensity and duration in Serbia, more frequent wildfires are expected, especially in south-eastern and eastern Serbia. The Modified Angstrom and Nesterov indices can be used to assess the risk of fire, including Serbia (Ratknić et al., 2019; Živanović and Tošić, 2020). Wildfires affect sustainable forest management and incur a substantial loss to forestry. In addition to the forest loss, wildfires also entail extensive ecological damage.

Restoration of forest ecosystems requires large financial resources, which is why these sites are often left to be naturally regenerated. It is also questionable whether it is financially justified to establish stands of the species that used to grow on the sites. Over 220,000 hectares of forest were burned in the years 2007 and 2012 alone within the western Balkan region, which includes parts of southern and eastern Europe (Hysa and Teqja, 2020). A large number of fires was registered in sessile oak forests in Serbia between 2003 and 2015. Therefore, the restitution of these forests has enormous economic importance. The restitution of forest land and the privatization of wood harvesting, transport and processing sector have probably had the highest impact on the evolution of the forestry sector and forest management in Romania (Abrudan et al., 2009). The process of forest restitution raises the issues of financing the project and estimating the profitability of the investment. Therefore, the purpose of this study was to perform an economic and financial analysis in order to determine the feasibility of the potential restitution of sessile oak coppice forests while taking into account ecological characteristics of the sites.

\section{Materials and Methods}

Cost-benefit analysis (static and dynamic bases of the project investment) was used to estimate the profitability of the investment into the restitution of sessile oak coppice forests in Serbia. The static estimate of the economic efficiency is based on simple static methods whose calculations take into account the parameters of only one i.e., the average year of the project exploitation period. This way of evaluating the effects of a project does not take into account the entire period of project implementation, but only a time segment. Because of their obvious shortcomings, the static methods have been replaced with dynamic methods of investment calculations which have been increasingly used in practice. Dynamic methods successfully solve some basic problems that static methods couldn't. These methods are also known as discount methods or multiple-period methods (Subić, 1999).

The value of wood production was calculated without taking into account the forest exploitation costs because they would make the analysis more complicated. These costs can significantly change with the changes in technology which also change the level of productivity. Another reason for excluding forest exploitation costs is the fact that the money invested in the exploitation cannot greatly change the amount and profitability of the invested funds because it remains tied up in the production for a relatively short time (Pudar, 1986). Besides, there is a trend to separate forest exploitation from silviculture.

The value of wood was calculated using the stumpage prices (JP 'Srbijašume', 2017), calculated according to the middle exchange rate RSD - EUR, at the end of December 2017 (Narodna banka Srbije, 2017). The 
analysis included the costs of coating stumps to prevent regrowth (including the purchase costs - 40,000 RSD, or 337.64 EUR per hectare) and cutting the shoots in the third year after the restitution was conducted and the new stands established (22,400 RSD, or 189.08 EUR per hectare). The subsidy granted by the state was treated as profit (for the organizations that perform the restitution). It amounted to $150,000 \mathrm{RSD}(1,266.14$ EUR) per hectare and covered the costs of soil preparation, seedlings, planting, ploughing and weeding (with the aim of establishing high forests).

The total forest area in Serbia amounts to 2,252.400 ha (29.1\% of its territory). State-owned forests account for $53.0 \%$ and privately-owned for $47.0 \%$ of the area (Banković et al., 2009). The calculation of the cost of buying forest land was not taken into account since the restitution of sessile oak forests was planned to be carried out on the areas with the well-defined ownership status.

The main questions to be answered are what will be produced and how much of it, i.e., which products will carry the greatest burden of repaying the financial liabilities and which discount rates should be applied to the assessment of profitability.

The profit was analyzed as the value of wood assortments at certain ages. The data on wood yield and the relevant prices of wood assortments were used to make tables showing the value of wood of the studied tree species on the sites of different quality classes. The obtained values were discounted at discount rates (i.e., certain amounts of inflows and outflows - net annual benefits were discounted using the compound interest account) ranging from 2 to $10 \%$, which produced several different 'net present values', depending on the applied discount interest rate. Net present value (NPV) is the difference between the value of cash inflows expected to be obtained from the investment and the value of cash outflows for its obtaining at the moment when we start using the investment (moment $\mathrm{n}=0$ ) (Subić, 2010). Accordingly, an investment is economically justified when its net present value is positive (NPV >0), i.e., when the ratio between the sum of cash inflows and the sum of cash outflows discounted at the initial moment of the exploitation period $(n=0)$ is above zero. The interest rate at which the sum of cash inflows obtained from the investment and discounted at a certain accounting moment is equal to the sum of cash outflows for obtaining and using the investment, discounted at the same accounting moment, is called the Internal Rate of Return (IRR) (Subić, 2010). In this context, an investment is considered economically justified when the internal rate of return is higher (or at least equal to) than the assumed calculative interest rate (discount rate) (IRR $\geq \mathrm{i}$ ). Discounting is a process of converting all the inflows and outflows that result from the investment and arise in different time periods to their present value, or to the value of a certain common moment (Vasiljević, 2006). Basically, discounting is a technique of converting future expected streams of benefits and costs to a present value (Gittinger, 1982). The initial (or present) value of a monetary amount that will be realized at some point in the future is determined by its discounting to a certain initial calculation moment. To discount means to reduce the value of the future costs and benefits for the amount of the interest received during the period of the interest bearing. The formula $1 /$ $(1+i) \times n$ or $(1+i)$ is called a discount factor. It shows the value of 1 monetary unit of future inflows and outflows at the beginning of a certain period of time (of $n$ years) at a certain interest (discount) rate ( $i$ ) (Andrić, 1991).

The value of wood production was calculated for different lengths of the production cycle (from 20 to 140 years). All the calculated values are expressed per unit area (1 ha).

The value of the wood assortments that were taken into account when calculating the value of wood production was determined using the stumpage prices of sawlogs class I (5,783 RSD, or 48.81 EUR), sawlogs class II (4,728 RSD, or 39.91 EUR), sawlogs class III (3,917 RSD, or 33.06 EUR), mine timber (4,852 RSD, or 40.95 EUR), cordwood (3,595 RSD, or 30.34 EUR), pulpwood (2,655 RSD, or 22.41 EUR) and forest residue (2,175 RSD, or $18.36 \mathrm{EUR})$.

The 'Cost-Benefit' Analysis included the costs that cannot be expressed in monetary terms (economic analysis). Unlike the financial analysis, the economic analysis studies the effects of sessile oak forests on biodiversity (including species, ecosystem, and genetic diversity), environment, living community and economy. 
Quantification of intangible benefits and costs has its own methodological background. Different 'scales' which express the relationships between otherwise unknown (real) benefits and costs are most commonly used. Expert methods in the sector of agriculture, forestry and water management, although mainly intended for decision-making, i.e., comparative analysis and selection of variants, can also be used as methods to determine the intangible benefits and costs of rural development and to implement the cost-benefit analysis. This possibility is based on the similarity between the multi-criteria methods of decision-making and the costbenefit analysis, which have the same pattern of evaluation, or maximization of the total benefit. The methods include the description of nominal variables, the method of aggregation and the evaluation of results. The starting points are nominal and ordinal variables (scales). The most important scales that can be applied in the rural development concerning sustainable agriculture are: Ordinal, Nominal, Interval, and Ratio Scales. Interval and ratio scales are also known as cardinal scales. The ordinal scale can be transformed into the cardinal scale which allows arithmetic operations to be performed. Transformations should be considered an important prerequisite for the quantification of ordinal scales. Transformations are also a prerequisite for the determination and construction of linguistic variables and the transfer of the results from the methods used into ordinal scales. The proposed formula, equation 1 , for the linear transformation of the ordinal scale is:

$$
\frac{\left(i-\frac{1}{2}\right)}{M}
$$

where, $i$ is the value of the ordinal scale and $M$ is the upper value of the scale.

The application of this method is aimed at determining the benefits that the restitution of sessile oak forests brings to the wider community, but which cannot be expressed in monetary terms. To assess the intangible costs and benefits we used the ordinal scale of 'Cost-Benefit' Analysis and the quantification (arithmetic operations) was done using the transformations that allow such procedures (Hastie et al., 2001, 2009). The results quantified by scoring the intensity of individual effects were used to perform the transformation. The intensity of the effects and scoring are shown in Table 1, where an ordinary scale was used to assess the intangible effects (intangible costs and benefits) on the environment, and transformations that allow such processing were used for quantitative data processing (arithmetic operations) (Hastie et al., 2001).

Table 1. Assessment of intangible effects on the environment

\begin{tabular}{|c|c|c|}
\hline Effect & Intensity & Score \\
\hline \multirow{4}{*}{ Positive or negative } & Very weak & $0-2$ \\
\cline { 2 - 3 } & Moderate & $3-5$ \\
\cline { 2 - 3 } & Significant & $6-8$ \\
\cline { 2 - 3 } & Very strong & 9 and more \\
\hline
\end{tabular}

Source: (Ratknić, 2018)

The process of restitution of sessile oak forests is in the analysis divided into two periods: the period up to 20 years of age of the new stands and the period between 21 and 120 years of age when the rotation of sessile oak high forests is completed. We selected 33 intangible effects (benefits and costs) that make relevant factors in the restitution of sessile oak forests destroyed by fires, Tables 4-7. 


\section{Results and Discussion}

\section{Tangible benefits and costs}

We analyzed the values of wood production for the observed tree species on the sites of different quality classes (I to V), with different lengths of the production cycle (20-140 years) and at discount rates of 2, 3, 4, 5, 6, 8 and 10\%, since according to Brumelle et al. (1991), wood production in forest plantations can be costeffective only at discount rates lower than $10 \%$

Some site classes bear slightly higher discount rates provided that the production cycle is short, Figures 1 and 2 .

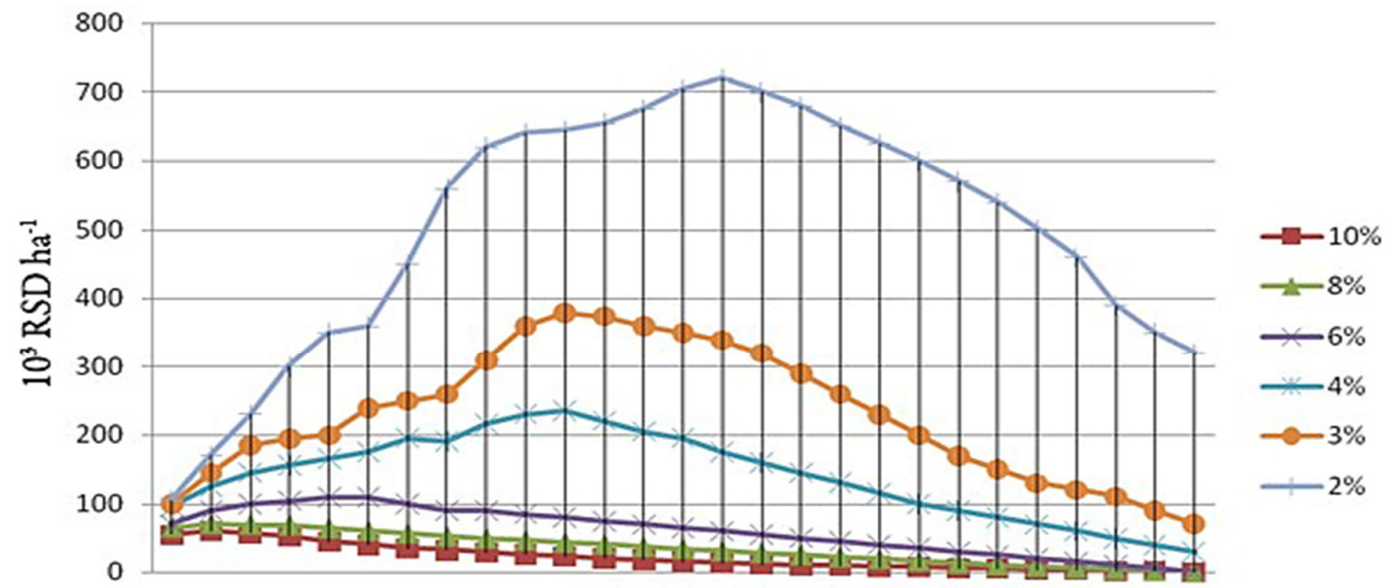

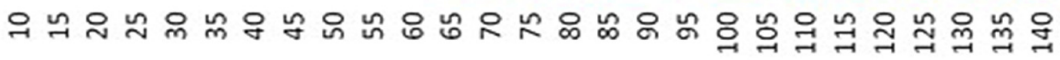

In years

Figure 1. Changes in the current value of wood with the age at different discount rates (sessile oak site class I)

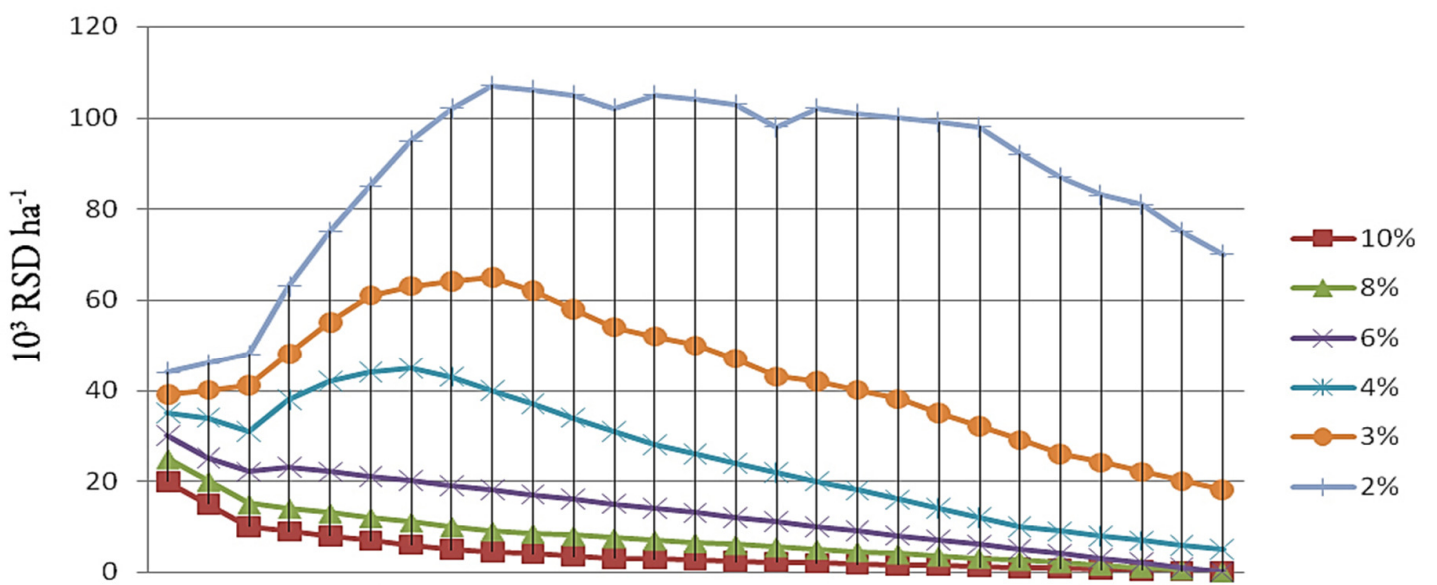

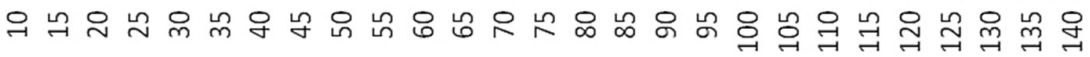

In years

Figure 2. Changes in the current value of wood with the age at different discount rates (sessile oak site class V) 
Having in mind the equality of benefits and costs, we determined the highest discount rates and the maximum length of the production cycle at which the project could be expected to break even, Table 2. Table 2 clearly shows that the discount rates at which the investment profitability is achieved are pretty lower than usual for similar projects (e.g., in agriculture). This indicates that wood production cannot bear regular interest rates, which should be taken into consideration when choosing the most appropriate interest rate. In this case, the project exploitation cannot cover the price of the invested funds, which means that no profit can be made.

Table 2. Maximum discount rates and break - even points for different site classes

\begin{tabular}{|l|c|c|}
\hline \multicolumn{1}{|c|}{ Site class } & Discount rate (\%) & Break - even point (year) \\
\hline I & 6.71 & 20 \\
\hline II & 5.50 & 25 \\
\hline III & 4.50 & 30 \\
\hline IV & 3.29 & 40 \\
\hline V & 2.06 & 50 \\
\hline
\end{tabular}

It can be concluded that the profitability of the investment can be achieved if wood production is selected as the main production objective, at different discount rates depending on the site class and the length of the production cycle, Table 3 .

Table 3. Break - even point of the production of wood in sessile oak forests at different discount rates (per age)

\begin{tabular}{|l|c|c|c|c|c|}
\hline Discount rate & Site class I & Site class II & Site class III & Site class IV & Site class V \\
\hline $2 \%$ & over 140 & over 140 & over 140 & over 140 & $75-80$ \\
\hline $3 \%$ & $125-130$ & $115-120$ & $105-115$ & $60-65$ & - \\
\hline $4 \%$ & $90-95$ & $80-85$ & $65-70$ & - & - \\
\hline $6 \%$ & $40-45$ & - & - & - & - \\
\hline $8 \%$ & - & - & - & - & - \\
\hline $10 \%$ & - & - & - & - & - \\
\hline
\end{tabular}

The obtained maximum discount rates are related to the length of rotation. In most cases, an increase in the discount rate shortens the length of rotation. This means that if long rotations must be selected from the aspect of the goal that is to be attained by establishing a forest plantation, the profitability can be achieved only at a discount (interest) rate below the maximum value. This points to the complexity of the problem. There are no easy solutions and each particular case requires a thorough analysis to decide on the best option which would meet both financial and economic objectives.

In some cases (site class and rotation), the profitability of the investment can be achieved at higher discount rates (4\%). This, to some extent, changes the current standing that investments in forestry can generally be profitable only at interest rates equal to or lower than $3 \%$. Higher interest rates can mainly be applied only to better site classes (I and II), while the interest rate for poorer site classes (III-V) ranges around the value of $3 \%$ or even lower than that, Table 3. It follows that the appropriate discount rate should be calculated for each particular case. The rate should correspond to the given tree species, site class and the length of the production cycle. The obtained value can be used to assess the investment profitability of the restitution of fire-destroyed sessile oak forests. The duration of the production cycle is in this case difficult to determine because the restitution of sessile oak forests involves natural regeneration and production of wood and other forest benefits which can continue in perpetuity without any new investments. This is the fundamental difference between the forestry and standard industrial or agricultural projects, which in most cases have clearly defined duration, after which new investments are required. 


\section{Intangible benefits and costs}

The method of determining the financial benefits and costs is accompanied by the so-called method of determining intangible benefits and costs (economic analysis). This analysis studies the effects of sessile oak forests on biodiversity (including species, ecosystem, and genetic diversity), environment, living community and economy. The results are presented by type of activity in Tables 4-8.

Table 4. Assessment of intangible benefits and costs of the planned project using the quantitative method - effects on biodiversity

\begin{tabular}{|c|c|c|c|c|c|}
\hline \multirow{3}{*}{$\begin{array}{l}\text { Effects by type } \\
\text { of activity }\end{array}$} & \multirow{3}{*}{ Intangible benefits and costs (effects) } & \multicolumn{2}{|c|}{$\begin{array}{l}\text { Significance and type } \\
\text { of effect }\end{array}$} & \multicolumn{2}{|c|}{ Transformation } \\
\hline & & \multicolumn{4}{|c|}{$\begin{array}{c}\text { Scoring of the effects in the period after the } \\
\text { amelioration (in years) }\end{array}$} \\
\hline & & to 20 & $21-120$ & to 20 & $21-120$ \\
\hline \multirow{14}{*}{ 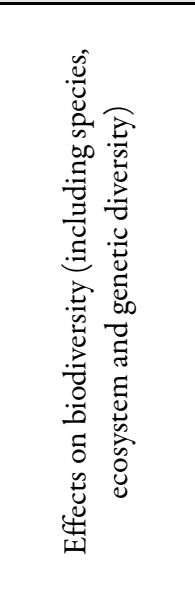 } & on macromycetes & -4 & +1 & -0.136 & 0.015 \\
\hline & on lichens & -4 & +1 & -0.136 & 0.015 \\
\hline & on moss & -3 & +1 & -0.106 & 0.015 \\
\hline & on the vascular flora & -10 & +5 & -0.318 & 0.136 \\
\hline & on Rotatoria & -3 & +2 & -0.106 & 0.045 \\
\hline & on the fauna of earthworms & -4 & +1 & -0.136 & 0.015 \\
\hline & on the diversity of snails & -2 & +1 & -0.076 & 0.015 \\
\hline & on the harvestman fauna & -2 & +1 & -0.076 & 0.015 \\
\hline & on the diversity of insects & -8 & +2 & -0.258 & 0.045 \\
\hline & on the diversity of amphibians and reptiles & -9 & +4 & -0.288 & 0.106 \\
\hline & on the diversity of birds & -9 & +5 & -0.288 & 0.136 \\
\hline & on mammals & -6 & +6 & -0.197 & 0.167 \\
\hline & on the ecosystem diversity & -10 & +5 & -0.318 & 0.136 \\
\hline & on the habitat fragmentation & -9 & +5 & -0.288 & 0.136 \\
\hline
\end{tabular}

Table 5. Assessment of intangible benefits and costs of the planned project using the quantitative method - effects on the living community

\begin{tabular}{|c|c|c|c|c|c|}
\hline \multirow{3}{*}{$\begin{array}{l}\text { Effects by type of } \\
\text { activity }\end{array}$} & \multirow{3}{*}{ Intangible benefits and costs (effects) } & \multicolumn{2}{|c|}{$\begin{array}{c}\text { Significance and type } \\
\text { of effect }\end{array}$} & \multicolumn{2}{|c|}{ Transformation } \\
\hline & & \multicolumn{4}{|c|}{$\begin{array}{c}\text { Scoring of the effects in the period after the } \\
\text { amelioration (in years) }\end{array}$} \\
\hline & & to 20 & $21-120$ & to 20 & $21-120$ \\
\hline \multirow{3}{*}{$\begin{array}{l}\text { Effects on the living } \\
\text { community }\end{array}$} & provision of recreational opportunities & 0 & +3 & - & 0.076 \\
\hline & social benefits (job opportunities) & 0 & +2 & - & 0.045 \\
\hline & effects on human health & +1 & +5 & 0.015 & 0.136 \\
\hline
\end{tabular}

Flannigan et al. (2009) believe that fires will be more frequent in the future, which will entail increasing dangers. They also predict that the fire season will be extended, and the fires themselves will intensify.

Wildfires have severe impacts on forest ecosystems. They can destroy everything - from the forest flora and vegetation, over the fauna to the habitats of plant and animal species. They can often stop their functioning over a long period of time. It can take decades or even centuries until these ecosystems are spontaneously revitalized to the natural state that was before the fire. First of all, the disappearance of rare, endangered and vulnerable plant and animal species results in reduced species and genetic diversity. Additionally, fires change the physical, chemical and microbiological properties of soil. They affect the climate, microclimate and water balance, disturb the water regime, reduce water supplies and cause floods. There are also difficulties in regulating the flow of water in burnt areas, which results in landslides and various forms of severe erosion (Marković, 2013). The vulnerability of forest ecosystems depends on the ability of natural ecosystems to resist 
negative impacts (Schröter et al., 2005). Protection of terrestrial biodiversity requires targeted efforts to protect, restore and promote the conservation and sustainable use of land and other ecosystems. These efforts are specifically aimed at maintaining forest sustainability, mitigating soil and natural habitat degradation processes, combating desertification and loss of biodiversity (Subić et al., 2017).

Table 6. Assessment of intangible benefits and costs of the planned project using the quantitative method - effects on the environment

\begin{tabular}{|c|c|c|c|c|c|}
\hline \multirow{3}{*}{$\begin{array}{c}\text { Effects by } \\
\text { type of } \\
\text { activity }\end{array}$} & \multirow{3}{*}{ Intangible benefits and costs (effects) } & Signific & $\begin{array}{l}\text { and type } \\
\text { ect }\end{array}$ & \multicolumn{2}{|c|}{ Transformation } \\
\hline & & \multicolumn{4}{|c|}{$\begin{array}{c}\text { Scoring of the effects in the period after the } \\
\text { amelioration (in years) }\end{array}$} \\
\hline & & to 20 & $21-120$ & to 20 & $21-120$ \\
\hline \multirow{10}{*}{ 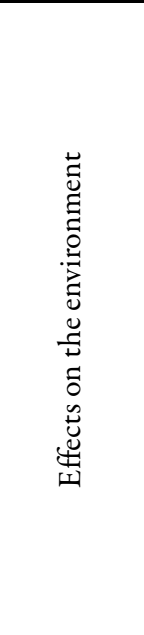 } & $\begin{array}{l}\text { ensuring the functioning of the water regime } \\
\text { (hydrological function) }\end{array}$ & 0 & +4 & - & 0.106 \\
\hline & protection of water against pollution & 0 & +4 & - & 0.106 \\
\hline & protection against harmful emissions & 0 & +4 & - & 0.106 \\
\hline & $\begin{array}{l}\text { regulation of soil composition and fertility (and } \\
\text { erosion control) }\end{array}$ & 0 & +3 & - & 0.076 \\
\hline & effect on the microclimate & 0 & +4 & - & 0.106 \\
\hline & $\begin{array}{l}\text { production of oxygen and purification of the } \\
\text { atmosphere }\end{array}$ & +1 & +4 & 0.015 & 0.106 \\
\hline & $\begin{array}{c}\text { carbon binding to wood volume and humic } \\
\text { substances formed under forest }\end{array}$ & +1 & +6 & 0.015 & 0.167 \\
\hline & $\begin{array}{l}\text { effect on the physical appearance of the scenery } \\
\text { during exploitation }\end{array}$ & -7 & +5 & -0.227 & 0.136 \\
\hline & rehabilitation of devastated areas & 0 & +2 & - & 0.045 \\
\hline & protection against noise & -3 & +2 & -0.106 & 0.045 \\
\hline
\end{tabular}

Table 7. Assessment of intangible benefits and costs of the planned project using the quantitative method - effects on the economy

\begin{tabular}{|c|c|c|c|c|c|}
\hline \multirow{3}{*}{$\begin{array}{c}\text { Effects by type } \\
\text { of activity }\end{array}$} & \multirow{3}{*}{ Intangible benefits and costs (effects) } & $\begin{array}{r}\text { Signific } \\
0\end{array}$ & $\begin{array}{l}\text { and type } \\
\text { ect }\end{array}$ & \multicolumn{2}{|c|}{ Transformation } \\
\hline & & \multicolumn{4}{|c|}{$\begin{array}{l}\text { Scoring of the effects in the period after the } \\
\text { amelioration (in years) }\end{array}$} \\
\hline & & to 20 & $21-120$ & to 20 & $21-120$ \\
\hline \multirow{6}{*}{ 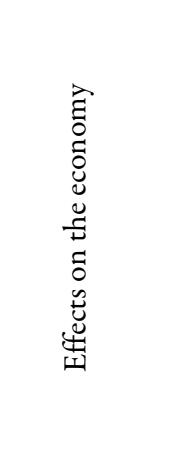 } & $\begin{array}{l}\text { provision of raw materials for processing } \\
\text { capacities }\end{array}$ & 0 & +4 & - & 0.106 \\
\hline & introduction of additional economic activities & +1 & +4 & 0.015 & 0.106 \\
\hline & $\begin{array}{l}\text { construction of commercial properties of } \\
\text { permanent significance }\end{array}$ & -4 & +5 & -0.136 & 0.136 \\
\hline & $\begin{array}{l}\text { effect on other economic activities (tourism, } \\
\text { hunting, etc.) }\end{array}$ & 0 & +4 & - & 0.106 \\
\hline & $\begin{array}{l}\text { use of other forest products (forest berries, } \\
\text { medicinal herbs, and mushrooms) }\end{array}$ & +1 & +4 & 0.015 & 0.106 \\
\hline & uncovered infrastructure costs & -2 & +2 & -0.076 & 0.045 \\
\hline
\end{tabular}

The assessment of the intangible benefits and costs of the restitution of sessile oak forests in Serbia started from the assumption that they will actually be realized (although it is not always a realistic possibility). According to the results of the analysis of intangible benefits and costs, the costs are much higher than the benefits in the first 20 years of the restitution process, Table 8 . The reason is that in the initial phase of the 
reconstruction, it is done on habitats completely destroyed by wildfires and until the normal functioning of the new habitat is established, the costs are greater than the benefits. In the period from 21 to 120 years - which is also the end of the sessile oak high forest rotation, the benefits do not exceed the costs. Therefore, the restitution of sessile oak forests, unlike beech forests (Ratknić et al., 2017), is not acceptable, Table 8. However, in each concrete case (microsite), an analysis should be carried out to determine whether the intangible costs are greater than the benefits.

Table 8. Quantification of the estimate of intangible benefits and costs

\begin{tabular}{|c|c|c|c|c|}
\hline \multirow[b]{2}{*}{ Effects by type of activity } & \multicolumn{2}{|c|}{ up to 20 years of age } & \multicolumn{2}{|c|}{ from 21 to 120 years of age } \\
\hline & Cost estimate & Benefit estimate & $\begin{array}{c}\text { Cost } \\
\text { estimate }\end{array}$ & Benefit estimate \\
\hline Effects on biodiversity & 2.727 & - & - & 0.997 \\
\hline Effects on the environment & 0.333 & 0.030 & - & 0.999 \\
\hline Effects on the living community & - & 0.015 & - & 0.257 \\
\hline Effects on the economy & 0.212 & 0.030 & - & 0.605 \\
\hline Total & 3.272 & 0.075 & - & 2.858 \\
\hline up to 20 years of age & \multicolumn{2}{|c|}{ Score (Benefit - Cost $)<0$} & \multicolumn{2}{|c|}{$0.075-3.272=-3.197$} \\
\hline from 21 to 120 years of age & \multicolumn{2}{|c|}{ Score $($ Benefit - Cost $)>0$} & \multicolumn{2}{|c|}{$2.858=2.858$} \\
\hline Total & \multicolumn{2}{|c|}{ Score $($ Benefit - Cost $)>0$} & \multicolumn{2}{|c|}{$(2.858+0.075)-3.197=-0.264$} \\
\hline
\end{tabular}

Source: Original

\section{Conclusions}

The investment in the restitution of sessile oak forests destroyed by wildfires can be profitable only if it is based on wood production and different discount rates can be applied depending on the site class. Depending on the site class, wood production may bear slightly higher interest rates compared to previous estimates which ranged mainly around 3\%. This primarily refers to better site classes, while on poor quality sites it may fall below the limit of 3\%. The interest rate and the assessment of investment profitability are also closely related to the length of the production cycle because the break-even point varies with the discount rate. At lower discount rates, it takes more time to reach the break-even point, while the period of time needed to reach the break-even point shortens with higher discount rates. The length of production cycle plays an important role in determining the investment profitability, especially regarding the relationship between the length of the production cycle and production targets (type and quality of wood assortments produced). Based on the analysis of intangible benefits and costs, it can be concluded that the costs outweigh the benefits (in total), which makes the restitution of sessile oak forests destroyed by wildfires unacceptable.

\section{Authors' Contributions}

Conceptualization: TR and MR; Methodology: TR, MR and JS; Calculations: TR, MR and JS; Literature: TR, MR, JS, ZP, GŠ, MA and SV; Data editing: TR, MR and JS; Writing - original draft preparation: TR, MR and ZP; Writing - review and editing: TR, MR, JS, ZP, GŠ, MA and SV; Visualization: TR, MR, GŠ, MA and SV; Funding acquisition: TR, MR, GŠ, MA and SV. All authors read and approved the final manuscript. 


\section{Acknowledgements}

This paper was realized as a part of the project LODE - AMD-826567-3 (Loss Data Enhancement for DRR and CCA Management). The LODE is funded by the European Commission - DG-ECHO - Directorate General for European Civil Protection and Humanitarian Aid Operations under the Program: Union Civil Protection Mechanism Prevention and Preparedness Projects in Civil Protection and Marine Pollution 20182020 and supported by Projects: 451-03-9/2021-14/200027, 451-03-9/2021-14 and 200189 of the Serbian Ministry of Education, Science and Technological Development.

\section{Conflict of Interests}

The authors declare that there are no conflicts of interest related to this article.

\section{References}

Allen CD, Macalady AK, Chenchouni H, Bachelet D, Mcdowell N, Vennetier M, ... Cobb N (2010). A global overview of drought and heat - induced tree mortality reveals emerging climate change risks for forests. Forest Ecology and Management 259(4):660-684. https://doi.org/10.1016/j.foreco.2009.09.001

Altun L, Kezik U, Kara O, Babur E (2016). Potential of water purification of Macka forest ecosystems in northeastern Turkey. Journal of Environmental Protection and Ecology 17(2):557-565. https://docs.google.com/a/jepejournal.info

Andrić J (1991). Troškovi i kalkulacije u poljoprivrednoj proizvodnji [Costs and calculations in agricultural production]. Faculty of Agriculture, Belgrade, Serbia.

Arabatzis G (2010). Development of Greek forestry in the framework of the European Union policies. Journal of Environmental Protection and Ecology 11(2):682-692. https://docs.google.com

Banković S, Medarević M, Pantić D, Petrović N, Šljukić B, Obradović S (2009). Šumski fond Republike Srbije - stanje i problemi [The growing stock of the Republic of Serbia - state and problems]. Glasnik Šumarskog fakulteta 100: 7-29. https://doi.org/10.2298/GSF0900007B

Brumelle SL, Carley JS, Vertinsky IB, Wehrung DA (1991). Evaluating silvicultural investments: a review in the Canadian context. Forestry Abstracts 52(9):804-856.

Christensen JH, Hewitson B, Busuioc A, Chen A, Gao X, Held I, ... Whetton P (2007). Regional climate projections. In: Solomon S, Qin D, Manning M, Chen Z, Marquis M, Averyt KB, ... Miller HL (Eds). Climate Change 2007: The Physical Science Basis. Contribution of working group I to the fourth assessment report of the intergovernmental panel on climate change. Cambridge University Press, Cambridge, United Kingdom and New York, NY, USA pp 848-940.

Flannigan M, Stocks B, Turetsky M, Wotton M (2009). Impacts of climate change on fire activity and fire management in the circumboreal forest. Global Change Biology 15(3):549-560. https://doi.org/10.1111/j.13652486.2008.01660.x

Gittinger JP (1982). Economic analysis of agricultural projects. The Johns Hopkins University Press $\left(2^{\text {nd }} e d\right)$, Baltimore and London. https://doi.org/10.1017/S0014479700022894

Hansen J, Ruedy R, Sato M, Lo K (2010). Global surface temperature change. Reviews of Geophysics 48(4):RG4004. https://doi.org/10.1029/2010RG000345

Hastie T, Tibshirani R, Friedman J (2001). The elements of statistical learning: data mining, inference, and prediction. Springer - Verlag ( $1^{\text {st }}$ ed), New York. https://doi.org/10.1007/978-0-387-21606-5

Hastie T, Tibshirani R, Friedman J (2009). The elements of statistical learning: data mining, inference, and prediction. Springer Series in Statistics (2 ${ }^{\text {nd }}$ ed), New York. https://doi.org/10.1007/978-0-387-84858-7

JP ‘Srbijašume’ (2017). Cenovnik šumskih proizvoda za 2017 [Price list of forest products for 2017]. Retrieved 2020 May 5 from https://srbijasume.rs/ssume/wp-content/uploads/2019/05/GlavCenovnik.pdf 
Marković M (2013). Sukcesije biljnih zajednica na požarištima planine Vidlič [Successions of plant communities on the burned sites of Vidlič mountain]. PhD Thesis, University of Kragujevac, Serbia.

Narodna banka Srbije (2017). Srednji kurs na kraju meseca u 2017 [Middle exchange rate at the end of the month in 2017]. Retrieved 2020 May 5 from http://www.cekos.rs/srednji-kurs-na-kraju-meseca-u-2017

Pudar Z (1986). Ekonomski efekti proizvodnje drveta topole, $P . \times$ euramericana (Dode) Guinier, cl. I-214 u zasadima različite gustine [Economic aspects of poplar wood production, Populus $\times$ euramericana (Dode) Guinier, cl. I214 in plantations of different densities]. Radovi Instituta za Topolarstvo 17:1-121.

Ratknić T, Milovanović J, Ratknić M, Šekularac G, Subić J, Jeločnik M, Poduška Z (2017). Analysis of the profitability of the restitution of fire - affected beech forests in Serbia. Applied Ecology and Environmental Research 15(4):1999-2010. http://dx.doi.org/10.15666/aeer/1504_19992010

Ratknić T (2018). Integralni model zaštite i upravljanje rizicima od šumskih požara u Republici Srbiji [Integral model of protection and forest risk management in the Republic of Serbia]. PhD Thesis, Singidunum University, Belgrade, Serbia.

Ratknić T, Ratknić M, Rakonjac N, Živanović I, Poduška Z (2019). Development of a national index for the purpose of forest fire risk assessments on the example of southern Serbia. Thermal Science 23(6A):3307-3316. https://doi.org/10.2298/TSCI190412276R

Schröter D, Zebisch M, Grothmann T (2005). Climate change in Germany - vulnerability and adaptation of climate sensitive sectors. In: Werscheck M, Willing P (Eds). Klimastatusbericht 2005. Deutscher Wetterdienst, Offenbach, Germany, pp 44-56. https://research.fit.edu

Subić J (1999). Characteristic of economic efficiency of investments in agriculture. In: Proceedings of the Third International Symposium on Investments and Economic Recovery. Academy of Economic Studies, Faculty of Management, Bucharest, Romania pp 422-432.

Subić J (2010). Specifičnosti procesa investiranja u poljoprivredi [Specifics of investing in Agriculture]. Monograph. Institute of Agricultural Economics, Belgrade, Serbia.

Subić J, Kljajić N, Jeločnik M (2017). Obnovljivi izvori energije i navodnjavanje u funkciji održivog razvoja poljoprivrede - ekonomski aspekti [Renewable energy sources and irrigation in the function of sustainable agricultural development - economic aspects]. Monograph. Institute of Agricultural Economics, Belgrade, Serbia.

Vasiljević Z (2006). Upravljanje investicijama [Investment management]. University 'Braća Karić', Faculty of Trade and Banking Janićije and Danica Karić, Belgrade, Serbia.

Živanović S, Tošić I (2020). Influence of climatic conditions on fire risk in Djerdap National Park (Serbia) - a case study of September 2011. Thermal Science 24 (5A):2845-2855. https://doi.org/10.2298/TSCI190905094Z
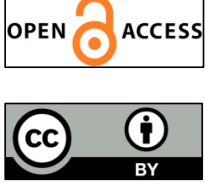

The journal offers free, immediate, and unrestricted access to peer-reviewed research and scholarly work. Users are allowed to read, download, copy, distribute, print, search, or link to the full texts of the articles, or use them for any other lawful purpose, without asking prior permission from the publisher or the author.

License - Articles published in Notulae Botanicae Horti Agrobotanici Cluj-Napoca are Open-Access, distributed under the terms and conditions of the Creative Commons Attribution (CC BY 4.0) License.

(c) Articles by the authors; UASVM, Cluj-Napoca, Romania. The journal allows the author(s) to hold the copyright/to retain publishing rights without restriction. 